Sains Malaysiana 49(7)(2020): 1479-1490

http://dx.doi.org/10.17576/jsm-2020-4907-01

\title{
Microplastic Abundance, Distribution, and Composition in Sungai Dungun, Terengganu, Malaysia
}

(Kelimpahan, Taburan dan Komposisi Mikroplastik dalam Sungai Dungun, Terengganu, Malaysia)

\author{
Tee Yang Hwi, Yusof Shuaib Ibrahim \& Wan Mohd Afiq Wan Mohd KhaliK*
}

\begin{abstract}
Scientific documentation on (Microplastics) MPs abundance in Malaysian waters is still limited and not fully understood. In this study, MPs occurrence in Sungai Dungun, Terengganu, Peninsular Malaysia was analysed. Sampling method was based on sieving $200 \mu \mathrm{m}$ of bulk water to collect surface water samples from five sites in the vicinity of potential source for MP abundance. Characterisation of MPs was accomplished by gravimetric and digital image processing (for quantification and morphology categorisation), and chemical composition identified by attenuated total reflectanceFourier infrared spectroscopy. The range concentration of MPs was 22.8 to 300.8 items $/ \mathrm{m}^{3}$ (mean $\left.102.8 \mathrm{item} / \mathrm{m}^{3}\right)$. It was recorded that most of the MPs found were black and transparent. The most frequent morphotypes were fibres, followed by fragments. Polypropylene $\left(\mathrm{C}_{3} \mathrm{H}_{6}\right) n$, polyacrylonitrile $\left(\mathrm{C}_{3} \mathrm{H}_{3} \mathrm{~N}\right) n$ and rayon were the dominant polymertypes of MPs analysed in this work. Metals $(\mathrm{Pb}<\mathrm{As}<\mathrm{Mn}<\mathrm{Zn}<\mathrm{Cu}<\mathrm{Fe}<\mathrm{Al})$ found within the MPs reported varied in terms of $\mu \mathrm{g} / \mathrm{mL}$. This study provided new insights into the understanding of MP levels in inland Malaysian freshwater environments.
\end{abstract}

Keywords: Freshwater; microplastics; surface water

ABSTRAK

Dokumentasi saintifik bagi kelimpahan MPs (mikroplastik) dalam persekitaran air di Malaysia masih terhad dan kurang difahami. Dalam kajian ini, kemunculan MPs di dalam Sungai Dungun, Terengganu, Semenanjung Malaysia telah dianalisis. Kaedah pensampelan berasaskan saringan air secara pukal dengan penapis $200 \mu$ m telah dilaksanakan dengan mengumpulkan sampel permukaan air dari lima lokasi yang berhampiran dengan titik sumber kelimpahan MPs. Pencirian MPs dilakukan secara gravimetri dan pemprosesan imej digital (bagi pengkuantitian dan pengelasan morfologi) dan komposisi kimia dikenal pasti melalui spektroskopi inframerah transformasi Fourier-pantulan penuh yang kecil. Julat kepekatan MPs ialah daripada 22.8 kepada 300.8 items $/ \mathrm{m}^{3}$. MPs paling kerap dijumpai berwarna hitam dan lutsinar. Jenis morfotip daripada kelas gentian adalah yang paling kerap dijumpai, diikuti oleh serpihan. Polipropilena $\left(\mathrm{C}_{3} \mathrm{H}_{6}\right) n$, poliarilonitril $\left(\mathrm{C}_{3} \mathrm{H}_{3} \mathrm{~N}\right) n$ dan rayon adalah polimer utama MPs yang dianalisis dalam kajian ini. Logam $(\mathrm{Pb}<\mathrm{As}<\mathrm{Mn}<\mathrm{Zn}<\mathrm{Cu}<\mathrm{Fe}<\mathrm{Al}$ ) daripada MP dilaporkan mempunyai variasi kepekatan pada julat $\mu \mathrm{g} /$ mL. Kajian ini telah memberi dimensi baru dalam memahami aras kelimpahan MPs di dalam persekitaran air tawar di Malaysia.

Kata kunci: Air permukaan; air tawar; mikroplastik

\section{INTRODUCTION}

Plastic pollution has become a controversial environmental issue with a growing concern around the world. Despite the large magnitude of waste being recycled or landfilled, still a considerable amount of plastic waste has entered the aquatic system (Wang et al. 2017). Plastic debris has been known to degrade into tiny particles when it is subjected to ultraviolet radiation, hydrolysis, or mechanical forces (Nie et al. 2019; Rose \& Webber 2019). Once degraded, the plastic endures changes in its physical properties, such as discoloration, loss of tensile strength, elasticity, and later becoming brittle and easily broken (Olivatto et al. 2019).
The small particles $(<5 \mathrm{~mm})$ are termed as microplastics (MPs). MPs may pose a potential risk to the environment due to their tendency to release contaminants such as metals, additives, and UV stabilisers. These contaminants act as a vector for hydrophobic pollutants, provide new habitats for microorganism colonisations or worse still, mistakenly ingested by organisms (Wagner et al. 2014).

Although major research endeavours have been focused on the effects of MPs on the marine environment, it can be observed that inland water is facing identical problems. Rivers are potential water sources and transport pathways of MPs to the oceans, mainly derived from 
terrestrial based activities ( $\mathrm{Li}$ et al. 2018; Rodrigues et al. 2018). In fact, rivers show predictable patterns when the derived source of pollution are related to industrial and human settlements (Dris et al. 2015; Eerkes-Medrano et al. 2015). Besides, agriculture practices like plastic mulching or the conversion of treated sludge to soil trigger is another source of plastic pollution into the river (Pico et al. 2019). Settlement rates of MPs from water column rely on their density by nature, potential for biofilm accumulation, and the prevailing water currents (Mendoza \& Balcer 2019).

MP abundance have been recorded in marine waters (Khalik et al. 2018), biota (e.g. bivalve, fish, zooplankton) (Amin et al. 2020; Ibrahim et al. 2016, 2017; Karbalaei et al. 2019), and even river sediments (Sarijan et al. 2018) but no scientific documents have been reported on the occurrence in Malaysian freshwater environments. In this study, the abundances, distribution, and morphological specificity of microplastics in the surface water samples from Sungai Dungun, Malaysia was investigated. This research could offer new insights for MP pollution and their fate in Malaysian freshwater systems.

Sungai Dungun is situated in Dungun district, Peninsular Malaysia. Riverine ecosystem is approximately $75 \mathrm{~km}$ in length and the watershed receives runoff from its main tributaries such as Sungai Loh, Sungai Telembuh, and Sungai Perlis before discharging into the South China Sea (Tahir et al. 2008). The river basin has a catchment area of about $1828 \mathrm{~km}^{2}$. Sungai
Dungun has been considerably subjected to various sources of contamination, including urban and industrial activities, fishing activities, and small-scale agriculture. Previous studies showed that this river had experienced deterioration of water quality linked to phosphate-based nutrients (Suratman et al. 2008), and metals (Aspin 2017). The river basin serves as a source of water for irrigation, aquaculture, water supply and wastewater dilution for the township of Kuala Dungun (Suratman et al. 2013).

\section{MATERIALS AND METHODS}

\section{STUDY AREA AND SAMPLE COLLECTION}

Water sampling was conducted at 5 different sites along the river in September and October 2019 (Figure 1). A global positioning system was used to determine the location of the sampling site (Table 1). The surface water within the top $20 \mathrm{~cm}$ was manually collected using a 20 L Flameer stainless steel bucket with a dimension of 36 (diameter) $\times 34 \mathrm{~cm}$ height. A total of $400 \mathrm{~L}$ surface water was collected from each site and each sample went through an aperture lab standard test sieve that was made of a $200 \mathrm{~mm}$ diameter stainless steel with a $60 \mu \mathrm{m}$ mesh size. The front and back of the sieve were rinsed carefully with Milli-Q water to transfer retained MPs into a $500 \mathrm{~mL}$ glass bottle. Before the laboratory analysis, MPs samples were placed in $4{ }^{\circ} \mathrm{C}$ refrigerator.
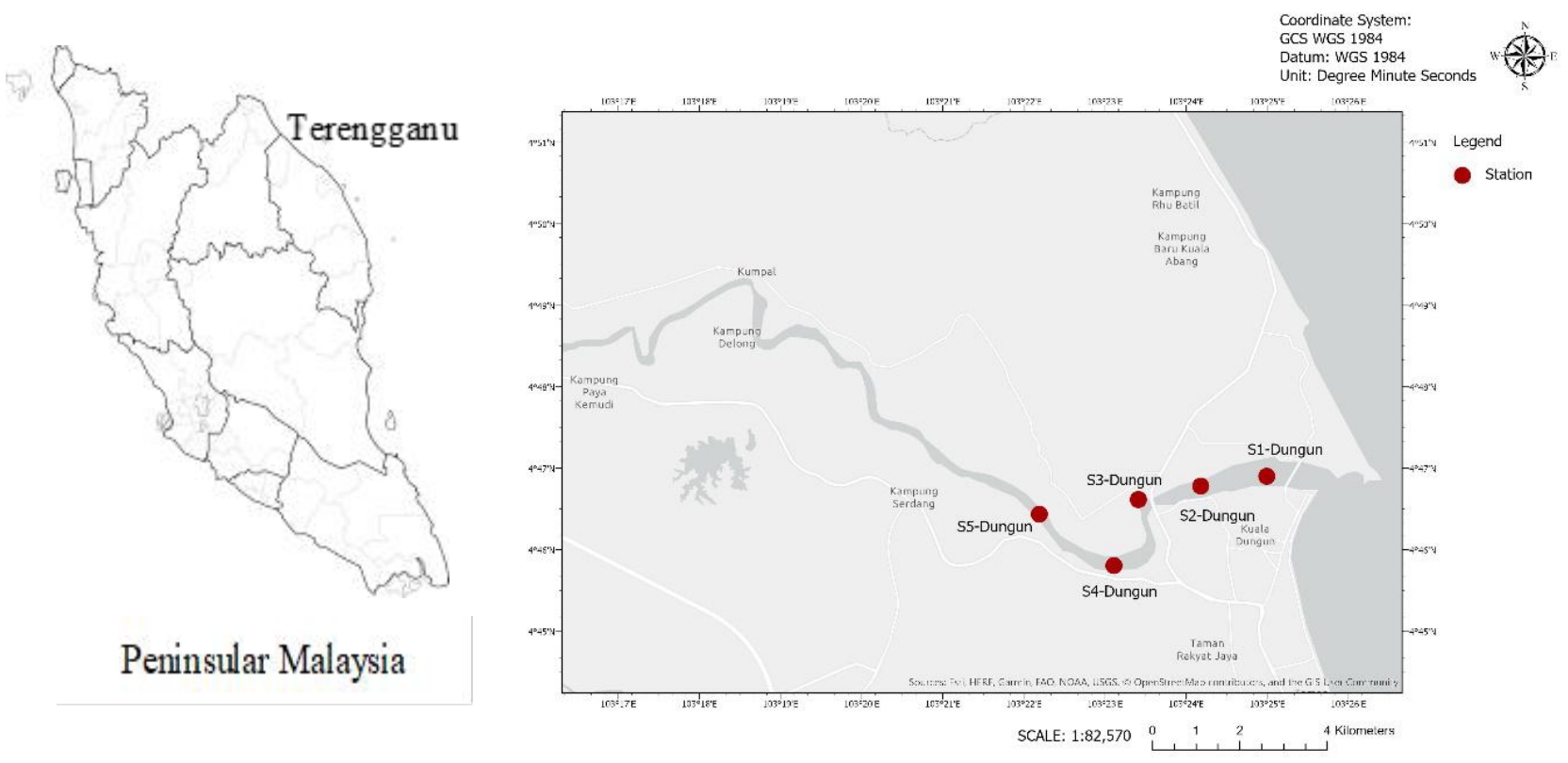

FIGURE 1. Location of sampling sites along Sungai Dungun are marked with red circles 
TABLE 1. List of the five sampling sites in the Sungai Dungun

\begin{tabular}{lcc}
\hline Station & Longitude $(\mathrm{N})$ & Latitude $(\mathrm{E})$ \\
\hline S1 & $4^{\circ} 46^{\prime} 49.5^{\prime \prime}$ & $103^{\circ} 25^{\prime} 06.6^{\prime \prime}$ \\
S2 & $4^{\circ} 46^{\prime} 46.8^{\prime \prime}$ & $103^{\circ} 24^{\prime} 43.3^{\prime \prime}$ \\
S3 & $4^{\circ} 46^{\prime} 38.8^{\prime \prime}$ & $103^{\circ} 23^{\prime} 42.7^{\prime \prime}$ \\
S4 & $4^{\circ} 45^{\prime} 51.2^{\prime \prime}$ & $103^{\circ} 23^{\prime} 24.3^{\prime \prime}$ \\
S5 & $4^{\circ} 45^{\prime} 59.0^{\prime \prime}$ & $103^{\circ} 22^{\prime} 38.9^{\prime \prime}$ \\
\hline
\end{tabular}

\section{SAMPLE PROCESSING}

First, to dissolve the natural organic material in the water samples, $500 \mathrm{~mL}$ water samples were treated with $10 \mathrm{~mL}$ $30 \% \mathrm{H}_{2} \mathrm{O}_{2}$ for $24 \mathrm{~h}$ at room temperature. Later, water samples were diluted with $500 \mathrm{~mL}$ Milli-Q water before being passed through $0.45 \mu \mathrm{m}$ glass microfiber membrane filter Whatman GF/C $47 \mathrm{~mm} \varnothing$ (Buckinghamshire, UK) using a filtering system that was facilitated with a vacuum pump. The membrane filter was placed in a clean glass petri dish and dried at $50{ }^{\circ} \mathrm{C}$ for $24 \mathrm{~h}$. The materials trapped by the membrane filter was then observed under a microscope.

\section{IDENTIFICATION AND QUANTIFICATION OF MICROPLASTICS}

MPs were detected and enumerated under an Olympus SZ51 stereomicroscope (Olympus Corp., Tokyo, Japan) with magnification range $0.8 \mathrm{x}-4 \mathrm{x}$. The isolated MPs were counted by classifying them according to four morphotypes namely fragment, fibre, film, and pellet. The characterisation of MPs were as follows: A fibre is a long and thin line with a cylindrical or slender shape, while a fragment is defined as a piece of debris. A film however appears in the shape of slices, and pellets comprised a three-dimensional sphere (Jiang et al. 2019; Nie et al. 2019).

Other physical characteristics such as colour were divided into eight classes namely black, blue, brown, green, red, purple, white, and transparent. The colour were recorded based on the dominant surface colour. During the sorting process, MPs were verified using the hot needle test. If MPs were virtually observed, they were collected using nonmagnetic tweezers and transferred into $12 \mathrm{~mL}$ glass vial with a screw cap containing 1 $\mathrm{mL}$ Milli-Q water. In addition, images of the MPs were captured by a Dino-Lite AM7023 handheld microscope equipped with the software program Dino Capture 2.0 Version 1.5.19 (ANMO Electronic Corp., Taiwan).
MPs were randomly selected for the next analysis using scanning electron microscope (SEM) model JEOL 6360 LA. Samples were spread on double-sided adhesive tape and coated with a thin film of evaporated gold. SEM images were taken with an optimised acceleration voltage of $10 \mathrm{kV}$ and a detector working at distances of approximately $2 \mathrm{~mm}$. MPs trapped on the membrane filter, were transferred into the $1.5 \mathrm{~mL}$ vial and placed in desiccators for up to 7 days to completely remove the water content.

It should be noted that visual identification of MPs alone is prone to false identification. In this study, MP compositions were subject to verification using Fouriertransform infrared spectroscopy (FTIR) analysis, IRTracer-100 (Shimadzu, Japan). Spectra were collected in reflectance mode in the range of $4000-400 \mathrm{~cm}^{-1}$, with a resolution of $4 \mathrm{~cm}^{-1}$ and the acquisition time set to $45 \mathrm{~s}$ for each measurement. In brief, $1 \mathrm{~mL}$ solution containing MPs in $12 \mathrm{~mL}$ vial was transferred into a $1.5 \mathrm{~mL}$ tube and centrifuged at $4000 \mathrm{rpm}$ in $20 \mathrm{~min}$. Supernatant (water) was removed, and the $1.5 \mathrm{~mL}$ tube was placed in a desiccator to remove remaining water. After 7 days, MPs were transferred on a diamond plate of FTIR using special design tool narrow-end tweezers.

\section{METAL CONTENT}

Metal contents were extracted from MP surfaces using a modified aqua regia extraction (Vedolin et al. 2018). Aqua regia solution was prepared by mixing $\mathrm{HCl}$ and $\mathrm{HNO}_{3}$ in a ratio of 3:1. Since MP sizes are generally small, MPs trapped on membrane filters were placed in $100 \mathrm{~mL}$ beakers. An amount of $30 \mathrm{~mL} \mathrm{HCl}, 10 \mathrm{~mL} \mathrm{HNO}_{3}$ and $10 \mathrm{~mL}$ deionised water were added into a beaker and placed onto a hotplate for $2 \mathrm{~h}$. After completing the process, the solution was filtered using GF/C Whatman filter (pore size $0.7 \mu \mathrm{m}$ ) and placed into a $50 \mathrm{~mL}$ vial. A blank membrane filter (without microplastics) was also subjected to the same procedure and was used to 
correct the metal concentrations. Final concentrations were determined by inductively coupled plasma-optimal emission spectrometry.

\section{DATA ANALYSIS}

In this study, an abundance of MPs was expressed by the number of particles per cubic metre of surface water (items $/ \mathrm{m}^{3}$ ). A one-way analysis of variance (ANOVA) was used to determine the differences in the abundance of the microplastics among the different sampling sites. Tests with $p<0.05$ were considered to be statistically significant. ArcGIS Pro 2.4.0 (Esri Inc, USA) was used to describe the geographic location of sampling sites. An ATR-FTIR spectrum was also used to determine the relative levels of surface oxidation and age of specific polymers. The carbonyl index for a single reading of tested sample was calculated by dividing the intensity of the carbonyl peaks with the intensity of the reference peaks. Carbonyl peaks were read at $1715-1735 \mathrm{~cm}^{-1}$. The reference peak, based on the literature, was $1458 \mathrm{~cm}^{-1}$ for PP (Prata et al. 2019, Rodrigues et al. 2018).

\section{QUALITY CONTROL AND ASSURANCE}

To control the level of contamination during sample collection and processing, pre-cleaned, acid washed glass bottles, and vials were used. Dust-free nitrile gloves and cotton lab coats were worn during the whole process. Blank analyses were conducted by operating the same manner using Milli-Q water and blank membrane filters. Membrane filters in petri dishes were exposed to ambient workplace chambers. The quality control analysis showed that negligible particles of MPs were found in the blank samples. Prior to analysing the samples in the petri dishes, the workplace was carefully cleaned and inspected stereo microscopically.

\section{RESULTS AND DISCUSSION}

\section{ABUNDANCE OF MICROPLASTICS}

MPs were found in all sampling sites located at the Sungai Dungun. The relative abundance of MPs in different samples is presented in Figure 2. MP concentrations vary between 38.7 and $300.8 \mathrm{item} / \mathrm{m}^{3}$. A mean value of $177.1 \pm 80 \mathrm{item} / \mathrm{m}^{3}$ (1st sampling) and $25.6 \pm 3.7 \mathrm{item} /$ $\mathrm{m}^{3}$ (2nd sampling), respectively. Abundance of MPs significantly differed between sampling events $(p<0.05$, $p=0.03$ ). During the observation under a microscope, 80 items (1st sampling) and 20 items (2nd sampling) were identified as non-plastics and were thus excluded in the next identification process.

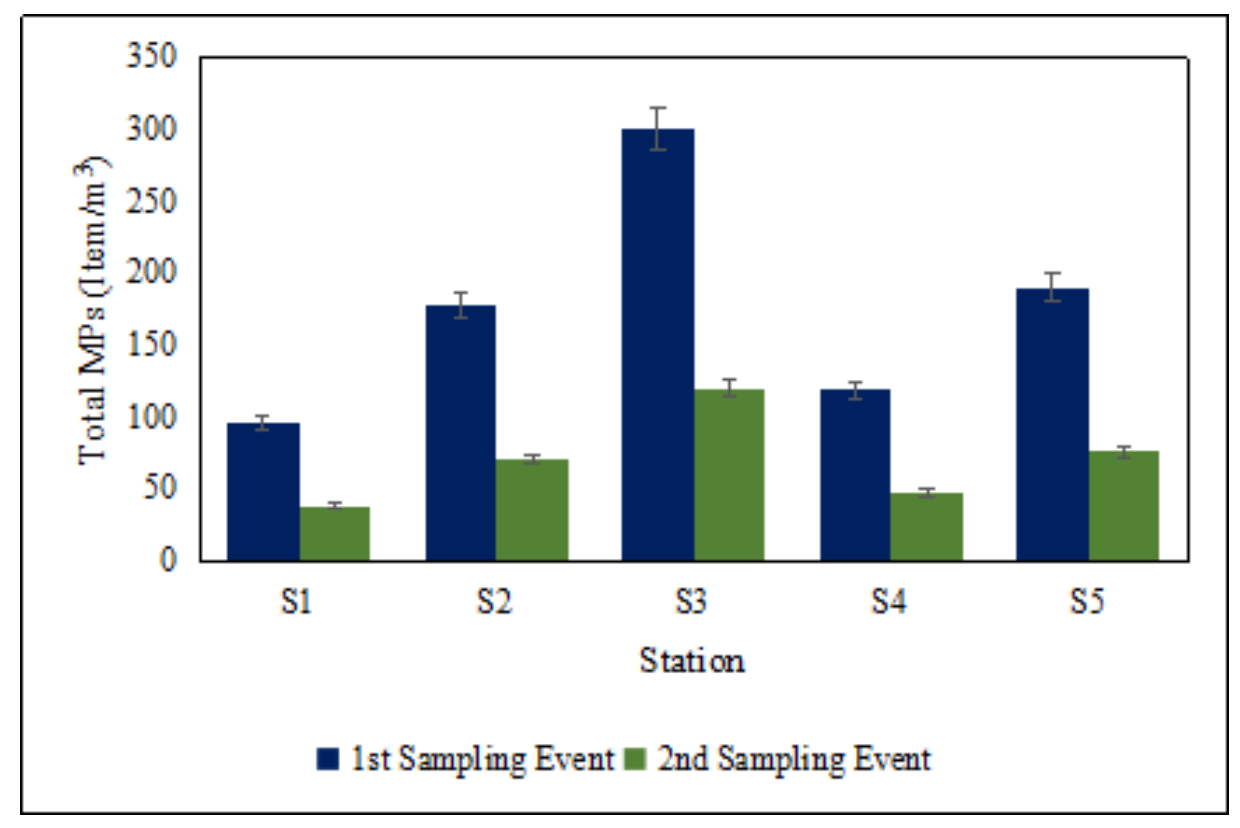

FIGURE 2. Variation of MPs abundance in water samples of Sungai Dungun 
Previous studies showed that there are many factors influencing the abundance and distribution of MPs, including human population, water current, entrance of wastewater and sewage, size and shape of MPs, shipping, fisheries or any related industries adjacent to marine area. In this study, five sampling sites were chosen, largely enhancing the representativeness of anthropogenic impact from Dungun local activities. Sungai Dungun is considered a hot spot for fishing activities, as it is connected to the South China Sea.

Spatially, relatively greater MP abundances were observed at S3. High abundance of MPs was expected since the sampling sites were nearby outlets of receiving waters. The riverine system in Sungai Dungun had received the domestic discharge from residential area such as Pengkalan Macang, Nibung, Sungai Buaya, Padang Jambu, and Tanjung Batu Villages. The heterogenicity of MP distribution was not only relevant to the available source of pollution but other environmental factors. For instance, tidal phenomena have significant roles to the efflux of MPs from riverine ecosystems to the South China Sea. It can be seen that the number of MPs recorded had been higher when researchers performed the first sampling event, two hours after the lowest tide, at $0848 \mathrm{am}$. Indeed, recorded data showed lower abundance on the second sampling event, which was four hours after the lowest tide at $0607 \mathrm{am}$. MP abundance is influenced by diurnal patterns that must be taken into account in the next research.

Comparatively, MPs in the other freshwater studies were also reported with relatively high abundances recorded in areas such as Pearl River, China (mean 2724 item $/ \mathrm{m}^{3}$ ), Yongjiang River (mean 2345 item $/ \mathrm{m}^{3}$ ), Nansha Islands, China (1773 item/m³), Nakdong River, Korea (mean 4760 item $/ \mathrm{m}^{3}$ ), rivers of the Tibet Plateau
( $\max 967$ item $/ \mathrm{m}^{3}$ ), respectively (Eo et al. 2019; Jiang et al. 2019; Lin et al. 2018; Nie et al. 2019). Rivers along urban areas experience greater impact of MP concentrations. This first assessment of MP occurrence in Sungai Dungun suggests that MP contaminants could be considered intermediate-low compared to the values reported at other Asian rivers.

\section{TYPE AND COLOUR OF MICROPLASTICS}

Morphotype fibres were the most abundant type of microplastics found in Sungai Dungun, accounting for 99.6 and $99.7 \%$ of the 1 st and 2 nd sampling events, respectively. Thus, the current data are in line with literature reports, which state that fibre MPs represents $59 \%$ of the microplastic proportion in collected freshwater samples from all over the world (Li et al. 2018). However, no foams or pellets were recorded in all the samples in this study, which can be explained by their high-density making it easy for them to be deposited in freshwater sediments. Fibre lengths varied largely, and this morphotype was shiny and uniform, but occasionally had breaks and small branches. Dominance of fibre MPs may be attributed to the breakdown of fishing gears like nets and ropes. The fibres were perhaps introduced into the water column through unintended disposal or abandonment during fishing-related activities. These activities have previously been described as important sources of plastic pollution (Zhao et al. 2014). As most of the sampling sites are proximal to residential areas, household sewage become secondary channels that convey fibres to the aquatic system via effluent discharge. Indeed, more than $90 \%$ of all collected MPs consist of fibre, thus it can be said that the major contribution of MPs in Sungai Dungun is made up of secondary MPs.
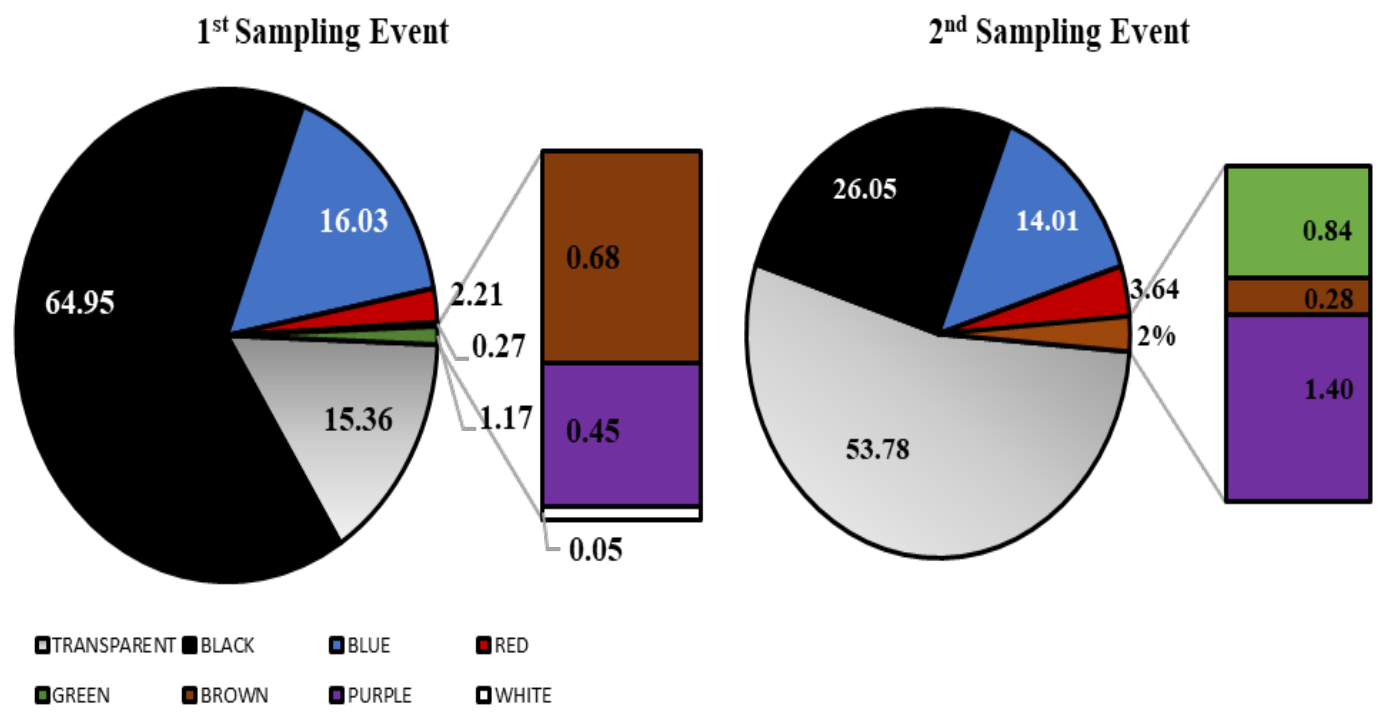

FIGURE 3. Composition of colored MPs sampled in Sungai Dungun 
The results were similar to previous freshwater studies in other Asian regions. For instance, MPs collected in Hanjiang River and Yangtze River elucidated that fibres were the most frequent morphotypes found during analyses (Wang et al. 2017). In 2014, fibre types were quantitatively found higher in Yangtze estuaries, China as reported by Zhao et al. (2014). Another study area in northwest China, Ding et al. (2019) had successfully documented the occurrence of MPs in Wei River, and fibres were smaller in size $(<0.5 \mathrm{~mm})$ becoming major contributors of total MPs. Despite contributions being in small proportions, $0.28-0.36 \%$, MP fragments provide strong evidence of secondary MPs as they are typically produced via the breakdown or fragmentation of larger plastic materials (Park et al. 2019). It is hard to find uniform patterns of fragment MPs, where the length of MPs shows a range of $1.22-1.30 \mathrm{~mm}$.
The results showed that the majority of plastic items in Sungai Dungun were black and transparent, accounting for 64.9 and $53.7 \%$, 1st and 2nd sampling events, respectively (Figure 3 ). Transparent fibres are commonly used in fishing nets and lines, and are linked to the frequent fishery activities in the study area. Similarly, Zhao et al. (2014) found transparent MPs were the most abundant in the Yangtze estuary accounting for $58.9 \%$ of the total MPs. Wang et al. (2017) reported $24.7 \%$ of the MPs detected in surface water of Wuhan China were transparent MPs. The ratio between transparent to colour MPs was 46.2:84.6\% where the larger proportion was contributed by colour MPs for both sampling events (Figure 4). Although the MPs collected showed a variety of colours in the data sets for this study, knowledge of the original sources of MP pollution remains inadequate.

\section{$1^{\text {st }}$ Sampling Event}

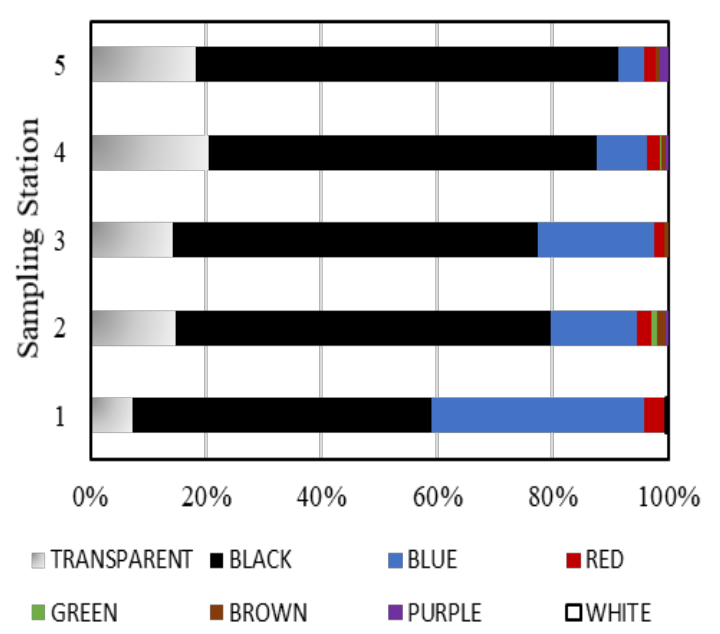

$2^{\text {nd }}$ Sampling Event

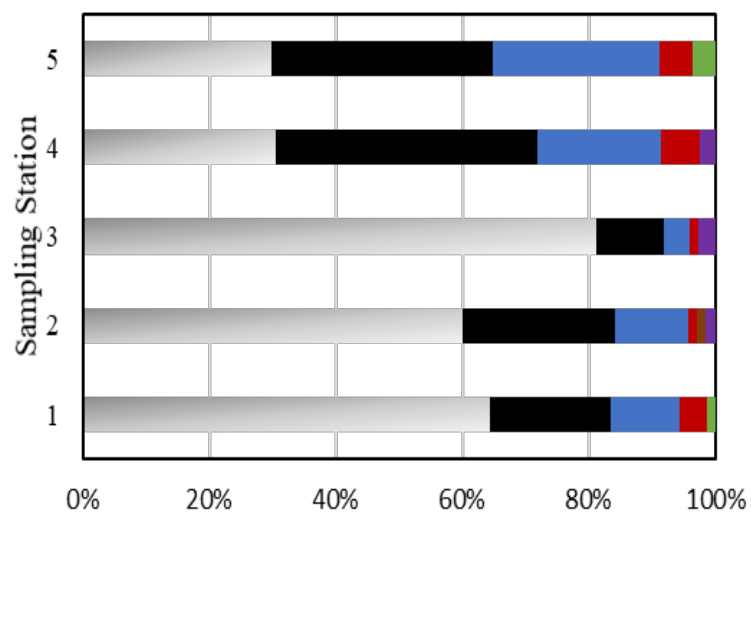

FIGURE 4. Variation of MPs color among sampling stations

\section{MORPHOLOGICAL CHARACTERISTICS OF MICROPLASTICS}

Surface features of MPs is one of the important elements to investigate, in order to examine whether plastic debris underwent mechanical, chemical or biological degradation ( $\mathrm{Li}$ et al. 2019). Figure 5 represents photographs of typical microplastics that were taken with a Dino-Lite camera attached to a stereoscopic microscope. It was obviously shown that fibres or fragments collected from the river water have a large variety of MP size. Therefore, it indicates that MPs present in the river water displayed a fragmentation process. Under a magnification ranging 500-8000x, changes were observed in the surface of MPs such as cracks, porosities, and incrustations. This suggests that collected MP faced a plastic degradation process. Certainly, the crack dimension observed an uneven pattern ranging from 0.28 to $3.5 \mu \mathrm{m}$ (wide) and from 2.45 to $24.7 \mu \mathrm{m}$ (length) as shown in Figure 6(a) and 6(c). Surface cracking increases the exposure of the interior plastic structure to the environment, so that MPs are susceptible to further decomposition, embrittlement and disintegrations over time (Pan et al. 2019). More formation of smaller particles e.g. nano-size was expected to occur when materials continuously received physical forces.

SEM images of fragments demonstrated that the surface of MPs was coarse and rugged. This proves the 
existence of a great deal of flakes, grooves, and adhering particles on the surface of different MPs (Figure 6(b) and 6(d)). Flaking involves the formation of brittle surface areas or layers on the polymer surface (Cooper \& Corcoran 2010). While, adhering particles show the existence of other substances that have agglutinated to larger items (Cooper \& Corcoran 2010). These characteristics forge superficial areas, thus enhancing their ability to absorb hydrophobic contaminants (Ding et al. 2019). In fact, physico-chemical changes of MPs such as surface area to volume ratio create an ideal condition for bacterial colonisation or formation of biofilms (Courtene-Jones et al. 2017; Hossain et al. 2019).

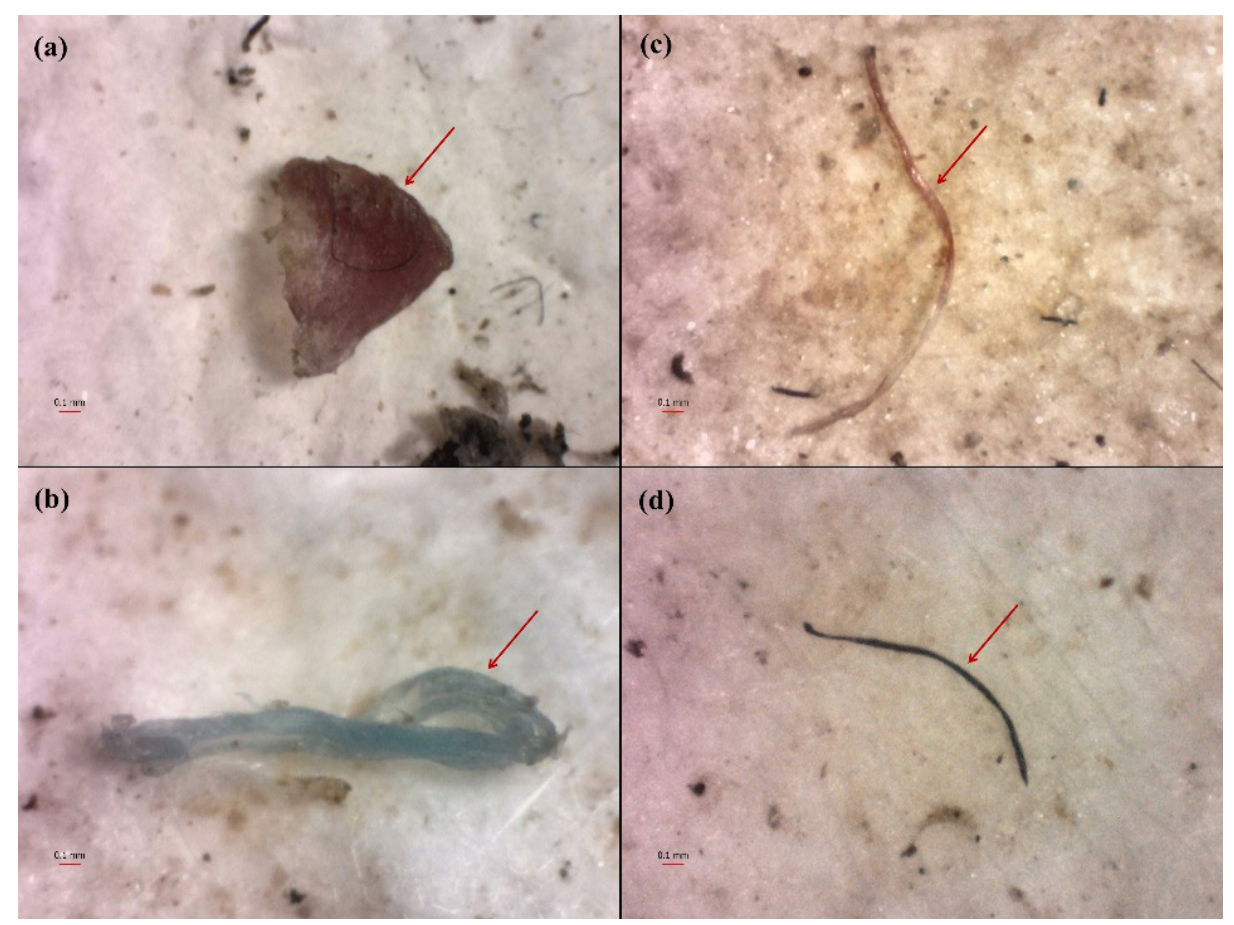

FIGURE 5. MPs shape found in water samples of Sungai Dungun: (a \& b) fragment, and (c \& d) fiber type

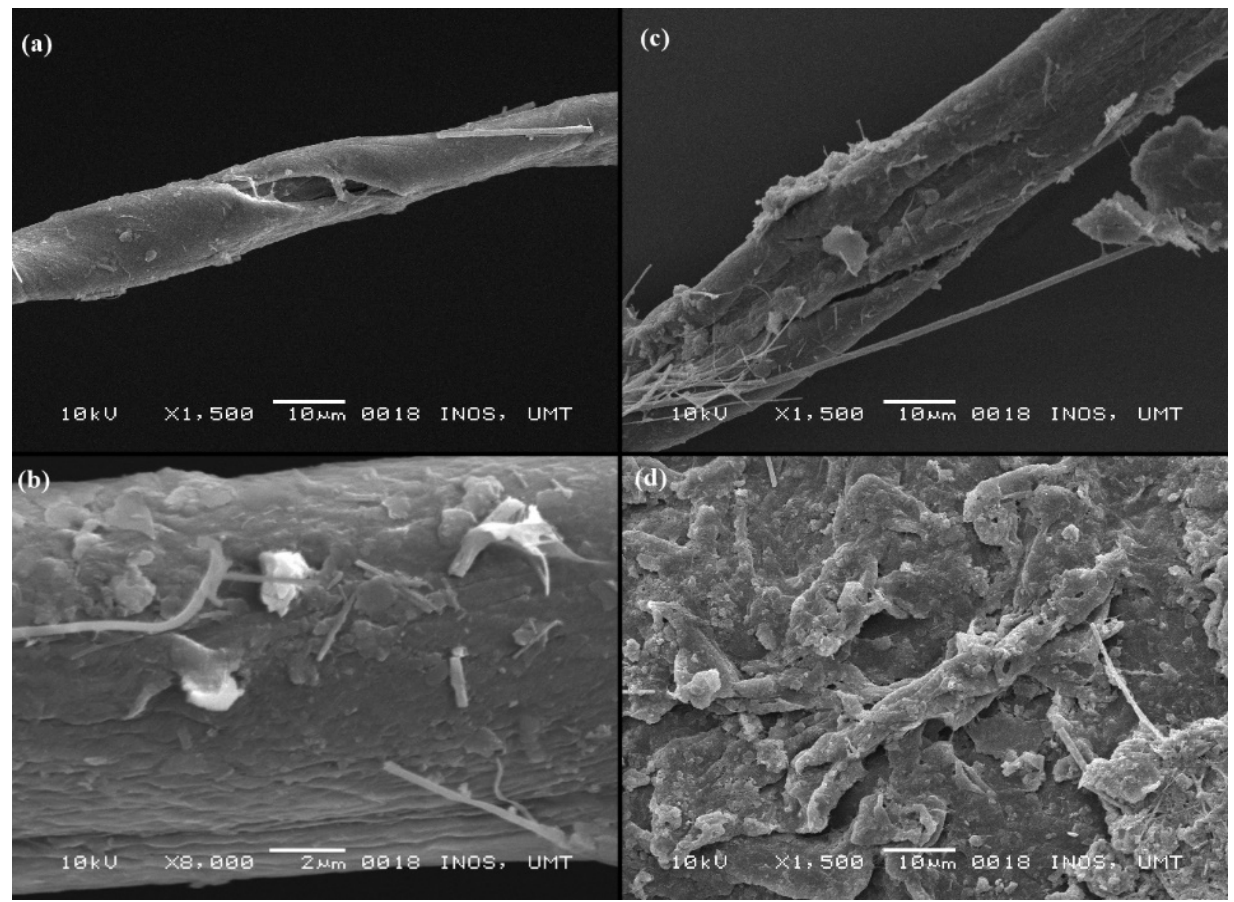

FIGURE 6. MPs surface observed under scanning electron microscope: (a \& c) crack, (b) adhering particle, and (d) flake formed on MPs surface of samples 


\section{IDENTIFICATION OF MICROPLASTICS}

Following the preliminary visual identification, suspected MPs collected were further identified using ATR-FTIR spectroscopy. Polyacrylonitrile (PAN) made up 44.4\% of all MPs, followed by Rayon, (RY) at 30.3\%, and polypropylene (PP) at $22 \%$. In the literature, it has been said that spectra compared using an electronic database should only be accepted if the match to a reference spectrum has $>70 \%$ similarity, which is adopted in this study (Jung et al. 2018).

PP produces main peaks around wave number regions $2920 \mathrm{~cm}^{-1}$ (C-H stretching), $2850 \mathrm{~cm}^{-1}$ (C-H stretching), $1458 \mathrm{~cm}^{-1}\left(\mathrm{CH}_{2}\right.$ bending), $1376 \mathrm{~cm}^{-1}\left(\mathrm{CH}_{3}\right.$ bending), $975 \mathrm{~cm}^{-1}$ ( $\mathrm{CH}_{3}$ rock), and $810 \mathrm{~cm}^{-1}\left(\mathrm{CH}_{2}\right.$ rock) as shown in Figure 7. PP items are usually buoyant due to lower densities $\left(0.83-0.91 \mathrm{gcm}^{-3}\right)$, regardless of their shape and size. This makes them readily transported by waters rather than being deposited in sediments (Wang et al. 2018; Zhang et al. 2020a). In addition, PP was frequently detected in previous MP investigations in the freshwater environments, such as $35.7 \%$ of total MPs detected in the Pearl River, China (Lin et al. 2018), Manas River, China (30.6\%), Qin River, China (39\%), Antuã River, Portugal (29.4\%), and Saigon River, Vietnam (4\%) (Lahens et al 2018; Rodrigues et al. 2018; Wang et al. 2019; Zhang et al. 2020b). In fact, 24\% of the main composition of MPs recorded in freshwaters worldwide was remarked as PP material (Li et al. 2019). PP is mainly applied in the manufacturing of packaging materials and fishing gears (Wang et al. 2017). Indeed, demographic area within Sungai Dungun relies on fishing activities as the main economic sources. Therefore, it is not surprising that PP was found in the collected water samples.

The calculated carbonyl index $\left(\mathrm{CI}_{\mathrm{pp}}\right)$ value of MPs polypropylene ranged $0.10-0.31$, thus showing MPs collected from the study area observed chemical changes known as the oxidation process. Oxidation levels were classified into $\mathrm{CI}<0.15$ (low), 0.16-0.30 (medium), and $>0.30$ (high), respectively (Cooper \& Corcoran 2010). Chemical changes of MPs could be confirmed by the appearance of a weak absorption peak at $1715 \mathrm{~cm}^{-1}$ indicating $\mathrm{C}=\mathrm{O}$ (ketone group) or organic acid likely due to the abiotic oxidation, which was prevalently absent in virgin polymers (Dyachenko et al. 2017; Wang et al. 2017). In addition, the characteristic band that had appeared at $3340 \mathrm{~cm}^{-1}$ was speculated to be a hydroxyl $(\mathrm{OH})$ group that had developed on a polymer chain link that was highly exposed to sunlight or had high oxygen availability (Cai et al. 2019). It could be confirmed that there were no traces of water in MP samples after they were completely dried within 7 days.

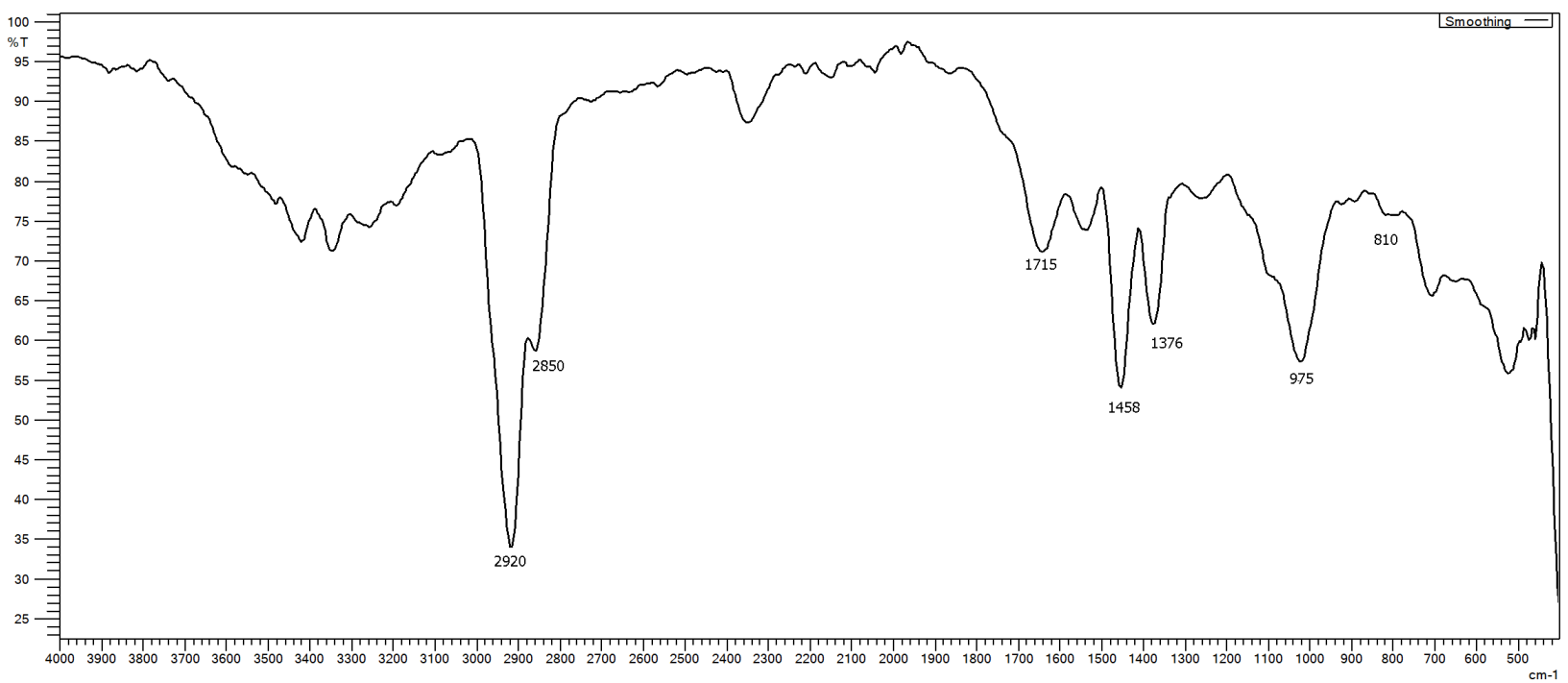

FIGURE 7. FTIR spectrum of PP materials collected during period of study 
PAN shows characteristic bands at wave number regions e.g. $2927 \mathrm{~cm}^{-1}$ (antisymmetric $\mathrm{CH}_{2}$ stretching), $2873 \mathrm{~cm}^{-1}$ (symmetric $\mathrm{CH}_{2}$ stretching), $2237 \mathrm{~cm}^{-1}$ (CN stretching), $1450 \mathrm{~cm}^{-1}\left(\mathrm{CH}_{2}\right.$ bending) as shown in Figure 8. Important features of acrylic groups are the existence of main peaks for nitrile stretching, $2237 \mathrm{~cm}^{-1}$. PAN has a higher density than water $\left(1.184 \mathrm{gcm}^{-3}\right)$, and tends to sink in aquatic ecosystems, thus is not commonly found in surface waters. Environmental conditions such as wind driven turbulence, tidal waves from the South China Sea can result in resuspension of MPs. The method for collecting water samples may also be one of the reasons that PAN was introduced into the water column. Since the manual approach of collecting surface water was applied, repetitive movement may have created water current and indirectly uplifted PAN from the sediment zone.

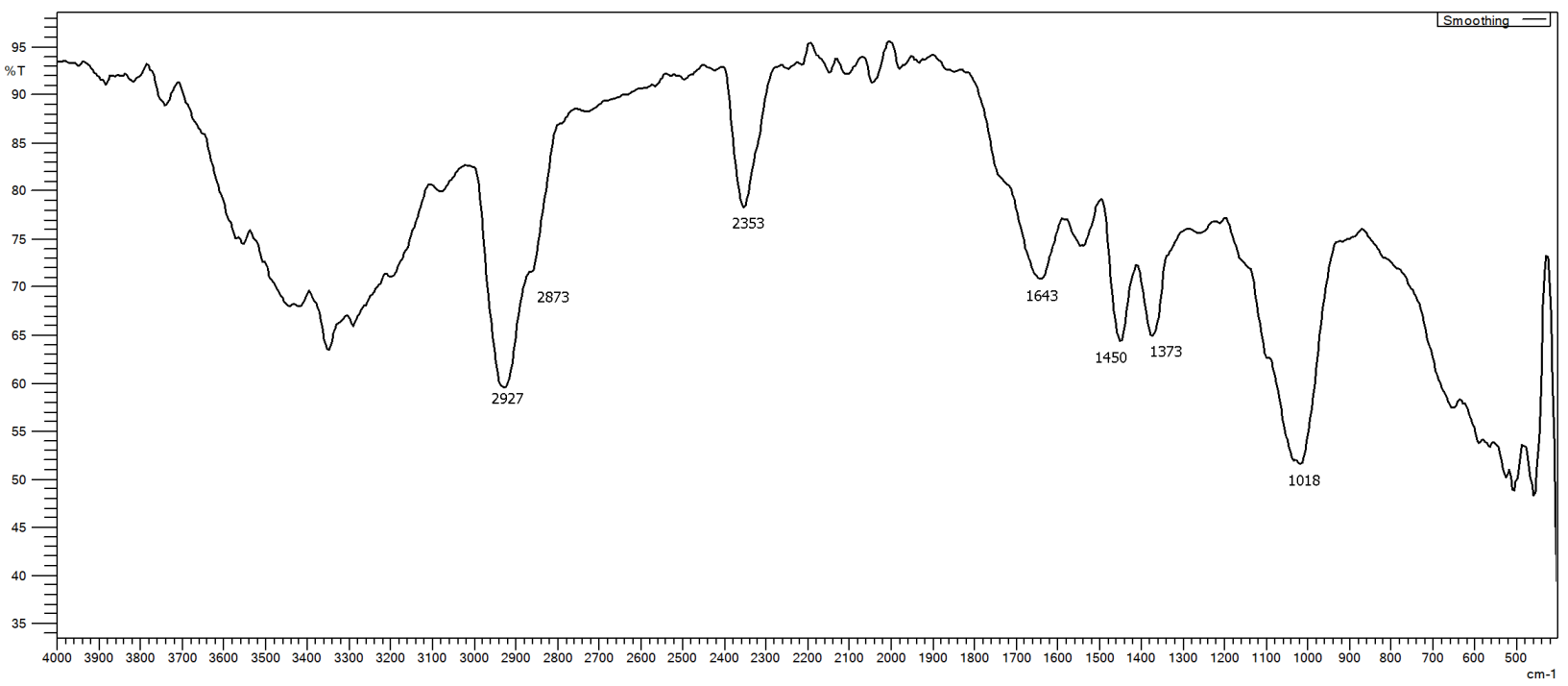

FIGURE 8. FTIR spectrum of PAN materials collected during period of study

Rayon shows main peaks around wave number regions e.g. $3352 \mathrm{~cm}^{-1}$ (OH stretching), $2924 \mathrm{~cm}^{-1}\left(\mathrm{CH}_{2}\right.$ stretching), $1643 \mathrm{~cm}^{-1}$ ( $\mathrm{H}_{2} \mathrm{O}$ bending), $1454 \mathrm{~cm}^{-1}(\mathrm{CH}$ bending), $1373 \mathrm{~cm}^{-1}$ ( $\mathrm{CH}$ bending), $1153 \mathrm{~cm}^{-1}$ (C-C stretching), $1056 \mathrm{~cm}^{-1}$ (C-OH stretching), $1029 \mathrm{~cm}^{-1}$ (C$\mathrm{OH}$ stretching) as shown in Figure 9. Rayon is commonly known as a semisynthetic cellulose-based polymer that has a high density of $1.50 \mathrm{gm}^{-3}$. Cai et al. (2019) suggested that the characteristic band at $1105 \mathrm{~cm}^{-1}$ had become a solid reference in distinguishing natural and semi-synthetic MPs. Indeed, rayon found in the study area did not have a clear peak at this position, and therefore, should be remarked as semi- synthetic fibre MPs. In addition, assignment band for $\mathrm{C}=\mathrm{O}$ stretching of an ester at $1735 \mathrm{~cm}^{-1}$ only appears if the material is produced from a natural fibre (Comnea-Stancu et al. 2017), and this peak did not appear in the RY spectrum.

RY was frequently detected in the sediment and biota and strangely recorded in the surface water. Literature studies by Luo et al. (2019) and Qu et al. (2018) also show the occurrence of RY in China freshwaters. Materials had been widely used in artificial textile materials, personal hygiene products, and fishing industries such as fishing net (Frias et al. 2016; Lusher et al. 2012; Pegado et al. 2018). Hence, abundance of RY in the study area could be a result of an indirect input through sewage discharge which was found at several points along Sungai Dungun. 


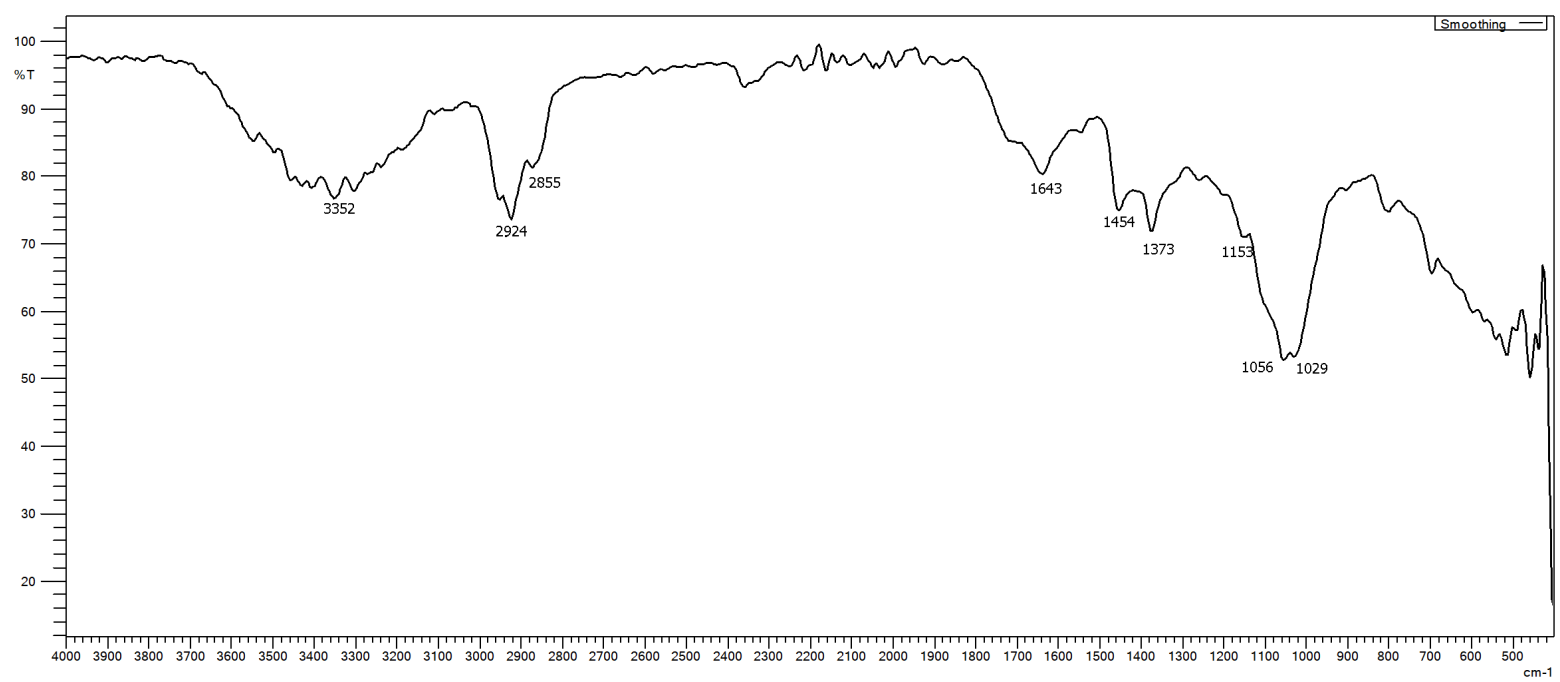

FIGURE 9. FTIR spectrum of RY materials collected during period of study

\section{METAL CONTENT ON MPS SURFACE}

Data related to the concentration of metals are listed in Table 2. For all metals, concentration accumulated on MPs varied between sampling location and that of samples comprising only of metals (e.g. As and $\mathrm{Al}$ ) detected in all collected samples. Total concentrations in increasing order were ranked as $\mathrm{Pb}<\mathrm{As}<\mathrm{Mn}<\mathrm{Zn}<\mathrm{Cu}<\mathrm{Fe}<$ Al. Metals present on the MP surface may have loaded during plastic manufacturing or chemicals absorbed in favourable conditions in the water column. For instance, $\mathrm{Zn}$ is widely used in the plastic industry namely zinc stearate as a stabiliser and $\mathrm{Pb}$ is often added to plastic materials to enhance a product's smoothness (Noik et al 2015). In a kinetic test run by Godoy et al. (2019), Pb metal has been noted to have high adsorption capacity in PP materials. Despite the low concentration levels reported, the results suggest that PP materials found in this area have become good vectors in transporting $\mathrm{Pb}$ pollutants. Arsenic based materials such as 10-10' oxybisphenoxarsine, is an example of a chemical used as a biocidal agent in the plastic manufacturing process (Noik et al. 2015). The metal absorption ability of MPs relies on modification on the surface area, $\mathrm{pH}$ changes, availability of organic matters, and anionic active sites (Brennecke et al. 2016; Turner \& Holmes 2015).

TABLE 2. Concentration level of metals content on MPs surface

\begin{tabular}{|c|c|c|c|c|}
\hline \multirow[t]{2}{*}{ Metals } & \multicolumn{4}{|c|}{ Concentration $(\mu \mathrm{g} / \mathrm{mL})$} \\
\hline & 1st Sampling & FD & 2nd Sampling & FD \\
\hline As & $0.3-5.2$ & 5 & $1.2-6$ & 5 \\
\hline $\mathrm{Al}$ & $7-79$ & 5 & $23-44$ & 5 \\
\hline $\mathrm{Cu}$ & nd -18 & 4 & $7-23$ & 5 \\
\hline $\mathrm{Fe}$ & nd - 18 & 4 & nd - 46 & 2 \\
\hline $\mathrm{Mn}$ & nd - 4 & 2 & nd - 15 & 2 \\
\hline $\mathrm{Pb}$ & nd - 2 & 3 & $2-4$ & 5 \\
\hline $\mathrm{Zn}$ & nd - 17 & 4 & nd - 3 & 3 \\
\hline
\end{tabular}

nd = not detected $; \mathrm{FD}=$ frequency of detection per sample 


\section{CONCLUSION}

The occurrence of MPs in a Malaysian river was successfully documented for the first time. Despite the fact that the density of MP concentration was considered intermediate-low, the heterogeneity of MP abundance provided latent information. Fibre became the most dominant morphotype in the surface water linked to the nature of the polymer. Morphological characteristics showed that MPs collected during the study had experienced an aging process either chemically or mechanically. Polymer composition elucidated from the FTIR spectra was linked to the existence of polypropylene, polyacrylonitrile, and semi-synthetic fibres known as rayon. A variation of seven metal content either inherited or absorbed on MPs had been recorded during this work. The role of MPs as vectors to metal pollution in Sungai Dungun is a new subject and must be considered in the next research strategies.

\section{ACKNOWLEDGEMENTS}

The authors acknowledge the Ministry of Higher Education and Universiti Malaysia Terengganu for the financial support under analytical and environmental chemistry course under Vote No. 401/2019 and FRGS/1/2016/WAB09/UMT/02/6 (Vote No. 59457).

\section{REFERENCES}

Amin, R.M., Sohaimi, E.S., Anuar, S.T. \& Bachok, Z. 2020. Microplastic ingestion by zooplankton in Terengganu coastal waters, southern South China Sea. Marine Pollution Bulletin 150: 110616.

Aspin, S.A. 2017. Determination of selected metals in sediment from Besut and Dungun river. Dissertation Dr. Phil, Universiti Malaysia Kelantan, Malaysia (Unpublished).

Brennecke, D., Duarte, B., Paiva, F., Caçador, I. \& CanningClode, J. 2016. Microplastics as vector for heavy metal contamination from the marine environment. Estuarine, Coastal and Shelf Science 178: 189-195.

Cai, H., Du, F., Li, L., Li, B., Li, J. \& Shi, H. 2019. A practical approach based on FT-IR spectroscopy for identification of semi-synthetic and natural celluloses in microplastic investigation. Science of The Total Environment 669: 692701.

Comnea-Stancu, I.R., Wieland, K., Ramer, G., Schwaighofer, A. \& Lendl, B. 2017. On the identification of rayon/viscose as a major fraction of microplastics in the marine environment: Discrimination between natural and manmade cellulosic fibers using Fourier transform infrared spectroscopy. Applied Spectroscopy 71(5): 939-950.

Cooper, D.A. \& Corcoran, P.L. 2010. Effects of mechanical and chemical processes on the degradation of plastic beach debris on the island of Kauai, Hawaii. Marine Pollution Bulletin 60(5): 650-654.

Courtene-Jones, W., Quinn, B., Gary, S.F., Mogg, A.O. \& Narayanaswamy, B.E. 2017. Microplastic pollution identified in deep-sea water and ingested by benthic invertebrates in the Rockall Trough, North Atlantic Ocean. Environmental Pollution 231: 271-280.
Ding, L., fan Mao, R., Guo, X., Yang, X., Zhang, Q. \& Yang, C. 2019. Microplastics in surface waters and sediments of the Wei River, in the northwest of China. Science of The Total Environment 667: 427-434.

Dris, R., Imhof, H., Sanchez, W., Gasperi, J., Galgani, F., Tassin, B. \& Laforsch, C. 2015. Beyond the ocean: Contamination of freshwater ecosystems with (micro-) plastic particles. Environmental Chemistry 12(5): 539-550.

Dyachenko, A., Mitchell, J. \& Arsem, N. 2017. Extraction and identification of microplastic particles from secondary wastewater treatment plant (WWTP) effluent. Analytical Methods 9(9): 1412-1418.

Eerkes-Medrano, D., Thompson, R.C. \& Aldridge, D.C. 2015. Microplastics in freshwater systems: A review of the emerging threats, identification of knowledge gaps and prioritisation of research needs. Water Research 75: 63-82.

Eo, S., Hong, S.H., Song, Y.K., Han, G.M. \& Shim, W.J. 2019. Spatiotemporal distribution and annual load of microplastics in the Nakdong River, South Korea. Water Research 160: 228-237.

Frias, J.P.G.L., Gago, J., Otero, V. \& Sobral, P. 2016. Microplastics in coastal sediments from Southern Portuguese shelf waters. Marine Environmental Research 114: 24-30.

Godoy, V., Blázquez, G., Calero, M., Quesada, L. \& MartínLara, M.A. 2019. The potential of microplastics as carriers of metals. Environmental Pollution 255: 113363.

Hossain, M.R., Jiang, M., Wei, Q. \& Leff, L.G. 2019. Microplastic surface properties affect bacterial colonization in freshwater. Journal of Basic Microbiology 59(1): 54-61.

Ibrahim, Y.S., Rathnam, R., Anuar, S.T. \& Khalik, W.M.A.W.M. 2017. Isolation and characterisation of microplastic abundance in Lates calcarifer from Setiu Wetlands, Malaysia. Malaysian Journal of Analytical Sciences 21(5): 1054-1064.

Ibrahim, Y.S., Azmi, A.A., Shukor, S.A., Anuar, S.T. \& Abdullah, S.A. 2016. Microplastics ingestion by Scapharca cornea at Setiu Wetland, Terengganu, Malaysia. Middle-East Journal of Scientific Research 24(6): 2129-2136.

Jiang, C., Yin, L., Li, Z., Wen, X., Luo, X., Hu, S. \& Liu, Y. 2019. Microplastic pollution in the rivers of the Tibet Plateau. Environmental Pollution 249: 91-98.

Jung, M.R., Horgen, F.D., Orski, S.V., Rodriguez, V., Beers, K.L., Balazs, G.H. \& Hyrenbach, K.D. 2018. Validation of ATR FT-IR to identify polymers of plastic marine debris, including those ingested by marine organisms. Marine Pollution Bulletin 127: 704-716.

Karbalaei, S., Golieskardi, A., Hamzah, H.B., Abdulwahid, S., Hanachi, P., Walker, T.R. \& Karami, A. 2019. Abundance and characteristics of microplastics in commercial marine fish from Malaysia. Marine Pollution Bulletin 148: 5-15.

Khalik, W.M.A.W.M., Ibrahim, Y.S., Anuar, S.T., Govindasamy, S. \& Baharuddin, N.F. 2018. Microplastics analysis in Malaysian marine waters: A field study of Kuala Nerus and Kuantan. Marine Pollution Bulletin 135: 451-457.

Lahens, L., Strady, E., Kieu-Le, T.C., Dris, R., Boukerma, K., Rinnert, E. \& Tassin, B. 2018. Macroplastic and microplastic contamination assessment of a tropical river (Saigon River, Vietnam) transversed by a developing megacity. Environmental Pollution 236: 661-671.

Li, J., Liu, H. \& Chen, J.P. 2018. Microplastics in freshwater systems: A review on occurrence, environmental effects, and methods for microplastics detection. Water Research 137: 362-374. 
Lin, L., Zuo, L.Z., Peng, J.P., Cai, L.Q., Fok, L., Yan, Y. \& Xu, X.R. 2018. Occurrence and distribution of microplastics in an urban river: A case study in the Pearl River along Guangzhou City, China. Science of The Total Environment 644: 375-381.

Luo, W., Su, L., Craig, N.J., Du, F., Wu, C. \& Shi, H. 2019. Comparison of microplastic pollution in different water bodies from urban creeks to coastal waters. Environmental Pollution 246: 174-182.

Lusher, A.L., McHugh, M. \& Thompson, R.C. 2012. Occurrence of microplastics in the gastrointestinal tract of pelagic and demersal fish from the English Channel. Marine Pollution Bulletin 67(1-2): 94-99.

Mendoza, L.M.R. \& Balcer, M. 2019. Microplastics in freshwater environments: A review of quantification assessment. Trends in Analytical Chemistry 113: 402-408.

Nie, H., Wang, J., Xu, K., Huang, Y. \& Yan, M. 2019. Microplastic pollution in water and fish samples around Nanxun Reef in Nansha Islands, South China Sea. Science of The Total Environment 696: 134022.

Noik, V.J., Tuah, P.M., Seng, L. \& Sakari, M. 2015. Fingerprinting and quantification of selected heavy metals in meso-and microplastics sampled from Santubong and Trombol Beach, Kuching, Sarawak, Malaysia. 2nd International Conference on Agriculture, Environment and Biological Sciences. pp. 53-58.

Olivatto, G.P., Martins, M.C.T., Montagner, C.C., Henry, T.B. \& Carreira, R.S. 2019. Microplastic contamination in surface waters in Guanabara Bay, Rio de Janeiro, Brazil. Marine Pollution Bulletin 139: 157-162.

Pan, Z., Guo, H., Chen, H., Wang, S., Sun, X., Zou, Q. \& Huang, J. 2019. Microplastics in the Northwestern Pacific: Abundance, distribution, and characteristics. Science of The Total Environment 650: 1913-1922.

Park, T.J., Lee, S.H., Lee, M.S., Lee, J.K., Lee, S.H. \& Zoh, K.D. 2019. Occurrence of microplastics in the Han River and riverine fish in South Korea. Science of The Total Environment 708: 134535.

Pegado, T.S.E.S., Schmid, K., Winemiller, K.O., Chelazzi, D., Cincinelli, A., Dei, L. \& Giarrizzo, T. 2018. First evidence of microplastic ingestion by fishes from the Amazon River estuary. Marine Pollution Bulletin 133: 814-821.

Pico, Y., Alfarhan, A. \& Barcelo, D. 2019. Nano-and microplastic analysis: Focus on their occurrence in freshwater ecosystems and remediation technologies. Trends in Analytical Chemistry 113: 409-425.

Prata, J.C., da Costa, J.P., Duarte, A.C. \& Rocha-Santos, T. 2019. Methods for sampling and detection of microplastics in water and sediment: A critical review. Trends in Analytical Chemistry 110: 150-159.

Qu, X., Su, L., Li, H., Liang, M. \& Shi, H. 2018. Assessing the relationship between the abundance and properties of microplastics in water and in mussels. Science of The Total Environment 621: 679-686.

Rodrigues, M.O., Abrantes, N., Gonçalves, F.J.M., Nogueira, H., Marques, J.C. \& Gonçalves, A.M.M. 2018. Spatial and temporal distribution of microplastics in water and sediments of a freshwater system (Antuã River, Portugal). Science of The Total Environment 633: 1549-1559.

Rose, D. \& Webber, M. 2019. Characterization of microplastics in the surface waters of Kingston Harbour. Science of the Total Environment 664: 753-760.
Sarijan, S., Azman, S., Said, M.I.M., Andu, Y. \& Zon, N.F. 2018 Microplastics in sediment from Skudai and Tebrau River, Malaysia: A preliminary study. MATEC Web of Conferences 250: 06012 .

Suratman, S. 2013. Distribution of total petrogenic hydrocarbon in Dungun River basin, Malaysia. Oriental Journal of Chemistry 29(1): 77.

Suratman, S., Tahir, N.M. \& Amin, M.S.M. 2008. A preliminary study on the behaviour of physical parameters and phosphatebased nutrients in Dungun River estuary, Terengganu. Sains Malaysiana 37(4): 331-336.

Tahir, N.M., Suratman, S., Shazili, N.A.M., Ariffin, M.M., Amin, M.S.M., Ariff, N.F.M.N.I. \& Sulaiman, W.N.H.W. 2008. Behaviour of water quality parameters during ebb tide in Dungun river estuary, Terengganu. Journal of Sustainability Science and Management 3(1): 1-10.

Turner, A. \& Holmes, L.A. 2015. Adsorption of trace metals by microplastic pellets in fresh water. Environmental Chemistry 12(5): 600-610.

Vedolin, M.C., Teophilo, C.Y.S., Turra, A. \& Figueira, R.C.L. 2018. Spatial variability in the concentrations of metals in beached microplastics. Marine Pollution Bulletin 129(2): 487-493.

Wagner, M., Scherer, C., Alvarez-Muñoz, D., Brennholt, N., Bourrain, X., Buchinger, S. \& Rodriguez-Mozaz, S. 2014. Microplastics in freshwater ecosystems: What we know and what we need to know. Environmental Sciences Europe 26(1): 12 .

Wang, G., Lu, J., Tong, Y., Liu, Z., Zhou, H. \& Xiayihazi, N. 2019. Occurrence and pollution characteristics of microplastics in surface water of the Manas River Basin, China. Science of The Total Environment 710: 136099.

Wang, W., Yuan, W., Chen, Y. \& Wang, J. 2018. Microplastics in surface waters of Dongting Lake and Hong Lake, China. Science of The Total Environment 633: 539-545.

Wang, W., Ndungu, A.W., Li, Z. \& Wang, J. 2017. Microplastics pollution in inland freshwaters of China: A case study in urban surface waters of Wuhan, China. Science of the Total Environment 575: 1369-1374.

Zhang, D., Cui, Y., Zhou, H., Jin, C., Yu, X., Xu, Y. \& Zhang, C. 2020a. Microplastic pollution in water, sediment, and fish from artificial reefs around the Ma' an Archipelago, Shengsi, China. Science of The Total Environment 703: 134768.

Zhang, L., Liu, J., Xie, Y., Zhong, S., Yang, B., Lu, D. \& Zhong, Q. 2020b. Distribution of microplastics in surface water and sediments of Qin river in Beibu Gulf, China. Science of The Total Environment 708: 135176.

Zhao, S., Zhu, L., Wang, T. \& Li, D. 2014. Suspended microplastics in the surface water of the Yangtze Estuary System, China: First observations on occurrence, distribution. Marine Pollution Bulletin 86(1-2): 562-568.

Microplastic Research Interest Group

Faculty of Science and Marine Environment

Universiti Malaysia Terengganu

21030, Kuala Nerus, Terengganu

Malaysia

*Corresponding author; email: wan.afiq@umt.edu.my

Received: 16 January 2020

Accepted: 24 March 2020 